\title{
HOW TO REACH AND KEEP A NOTE 6?
}

\author{
Como chegar e manter a nota 6 ?
}

Alberto Azoubel Antunes

\begin{abstract}
A B S TR A C T
Objective: To describe the main measures adopted in order to raise the concept of USP Urology program, and thus be able to help other programs with similar shortcomings to remedy these problems. Method: We highlighted the measures taken between the years 2005 and 2013 which contributed to the CAPES elevation of the Postgraduate Program of the USP Urology concept. Results: It was created new disciplines focused on researchers and teachers training rather than clinical aspects. Specific research areas have been created for each permanent teacher, and the theses and dissertations became linked research lines. The entire student body and faculty not interested or who had performance below the average was off the program. Was encouraged fundraising culture into program. It was also highlighted the creation of online medical record, where the clinical data of all patients treated at the Urology Division were stored. Conclusion: Rigorous selection of motivated faculty and students, able to create adequate infrastructure and achieving financial resources, is of fundamental importance for the consolidation of a postgraduate program.
\end{abstract}

Key Words: Postgraduate education. Educational evaluation. Higher education. Health research evaluation. Program evaluation and research instruments. Staff development

\section{INTRODUCTION}

mproving the quality of postgraduate programs is a critical step in the development of the society. In Brazil, the Higher Education Personnel Improvement Coordination (CAPES), foundation of the Ministry of Education, plays a key role in the expansion and consolidation of stricto sensu postgraduate programs in all states of the Federation. CAPES has an evaluation system based on strict criteria that serves as an instrument for the university community in the search for a standard of academic excellence for masters and doctorates. This system results in a concept ranging from 3 to 7, where the concept programs 6 and 7 are considered international standard.

When we assumed the Postgraduate Urology Program, Faculty of Medicine, University of São Paulo (USP), the CAPES program concept was 3 in triennial assessment of 2004. During this period, the USP Urology program had published only 35 articles in journals indexed by PubMed. Due to the imminent risk of disqualification, a fact that would bring great harm to our department and to the Brazilian urology, a series of measures were adopted in order to improve program concept.

These measures took effect quickly, and the next triennial review in 2007, our concept had risen to 5. The number of articles published during the triennium raised to 56. The commitment and continued effort even more elevated this concept that the triennial evaluation 2010 and 2013 received a score of 6, accrediting our party so to be part of the Academic Excellence Program (PROEX) CAPES; from 2014 were published an average of 115 articles in a three-year period in the latter two assessments.

The purpose of this article is to describe the main measures adopted in order to raise the concept of USP Urology Program, and thus be able to help other programs with similar shortcomings to remedy these problems.

\section{METHODS}

For this paper, were highlighted the measures taken between 2005 and 2013 that contributed to rise the concept of the postgraduate program at the USP Urology.

\section{RESULTS}

In 2004 the Urology Program had low scientific production, and the disciplines were characterized more as lato than stricto sensu. And more, by that time was prevalent the view that postgraduation was specialization in higher level than teach/research student formation. Moreover, it was not possible to characterize any line of research in the program, as projects had entirely different issues. This distortion of the current understanding hampered the development of original studies at high-level, a fact which affected our concept.

Thereafter proposals have been made to improve this concept (Figure 1). The first was to create a new discipline program focused on the training of researchers and teachers rather than clinical experts. They came to encompass subjects such as epidemiology in research, teaching in surgery, medical genetics principles and bases of urological diseases - from the bench to the hospital bed, etc. Specific research areas have been created for each permanent teacher, and theses and dissertations became linked to these lines. The inter-institutional projects were also reviewed and linked to these lines of research. Finally, the most difficult steps were the point of view of human material. The entire student body and faculty not really interested or were below average performance was put off the program. In parallel was instituted rigorous selection of students and teachers with high scientific production and strong commitment to teaching and research.

Another factor that helped in a unique way to leverage the program was early institutional fundraising culture. Thus, undergraduate research projects, dissertations and theses, routinely requested fundraising from federal and state funding agencies. At the end of 2013, the urology already had 48 projects financed by the Research Foundation for State of São Paulo (FAPESP) and five by the National Council for Scientific and Technological Development (CNPq). This measure enabled the execution of more complex projects and greatly improved the quality of scientific production.

\section{Novo programa de Disciplinas \\ 2. Teses vinculadas às linhas de pesquisas \\ 3. Redefinição dos projetos inter-institucionais \\ 4. Desligamento dos alunos insuficientes \\ 5. Seleção rigorosa dos alunos \\ 6. Recredenciamento dos docentes \\ 7. Cultura de captação de recursos}

\section{FIGURE 1 - Proposals to improve the postgraduate concept of USP Urology}

To renovate improve the physical infrastructure, the Urology Division raised funds from the private sector. Among the actions taken with this support included: library, amphitheater, outpatient and ward of urology reform, construction of two surgical arenas within the ward, basic research lab reform of Urol- 
ogy (Laboratory of Medical Research 55 - LIM-55), construction of a Teaching and Research Center of Surgery (CEPEC), which perform laparoscopic procedures on animals weekly by residents and postgraduate students, and construction of the simulation center in robotic surgery. It also highlights the creation of online medical record, where the clinical data of all patients treated at the Urology Division are stored. This chart can be accessed at any unit of the Division, including the amphitheater, library, wards, operating room and clinic.

\section{DISCUSSION}

The involvement of committed and dedicated people is fundamental to the creation of a postgraduate program. In this context, we understand that a motivated group is able to multiply resources and realize original research at high technical-scientific level. This movement is usually able to motivate the younger, and thus generate a vicious cycle that will further improve the scientific production. The most rigorous selection of students for the Urology Program also brought greater interest in internships abroad in the sandwich doctorate format, contributed to the development of projects with international support.

Regarding the financial aspect, recent surveys reveal that the support of the private sector is crucial for research and development $(R \& D)$ in the world. While in developed countries private firms bear up to $75 \%$ of expenditure on R\&D in Brazil the state still pays for half of these expenditures. In absolute numbers, it is clear that it is more difficult to do high-level research in Brazil: while in 2012 Brazil spent about 24.2 billion R\$ (reais) in R\&D, the United States spent about 398.2 billion dollars. With fewer resources, the support of the private sector is even more relevant. With projects being relevant, consistent and with high social appeal, urology was able to raise funds from the private sector.

\section{CONCLUSIONS}

Rigorous selection of motivated faculty and students, able to create adequate infrastructure and achieving financial resources, is of fundamental importance for the consolidation of a postgraduate program.

\section{RESUMO}

Objetivo: Descrever as principais medidas adotadas com o intuito de elevar o conceito do programa da Urologia da FMUSP, e desta forma poder ajudar outros programas com deficiências semelhantes a sanar estes problemas. Método: Foram destacadas as medidas adotadas entre os anos de 2005 e 2013 que contribuíram para a elevação do conceito do Programa de Pós-Graduação em Urologia da FMUSP. Resultados: Criou-se um novo programa de disciplinas voltado para a formação de pesquisadores e professores ao invés de especialistas clínicos. Foram criadas linhas de pesquisa específicas para cada orientador permanente, e as dissertações e teses passaram a ser vinculadas a estas linhas. Todo o corpo discente e docente que não se mostrava interessado ou que possuía desempenho abaixo da média foi desligado do programa. Estimulou-se a instituição de cultura de captação de recursos. Destaca-se ainda a criação do prontuário online, onde os dados clínicos de todos os pacientes atendidos na Divisão de Urologia ficam armazenados. Conclusão: Seleção rigorosa do corpo docente e discente motivado, capaz de criar infra-estrutura adequada e de conseguir recursos financeiros é de fundamental importância para a consolidação de um programa de pós-graduação.

Descritores - Educação de pós-graduação. Avaliação educacional. Educação superior. Avaliação da pesquisa em saúde. Avaliação de programas e instrumentos de pesquisa. Desenvolvimento de pessoal.

\section{REFERENCES}

1. Relatorio de Avaliação 2007-2009 - Trienal 2010. Área de avaliação: Medicina III. Disponivel em: http://trienal.capes.gov.br/ wp-content/uploads/2011/03/MEDICINA-III-REL-AVAL.pdf. Acesso em 05/06/2015.

2. Relatorio de Avaliação 2010-2012 - Trienal 2013. Área de avaliação: Medicina III. Disponivel em: https://docs.google.com/viewer?a=v\&pid=sites\&srcid=Y2FwZXMuZ292 LmJyfHRyaWVuYWwtMjAxM3xneDo2MDZiZmFhYTFmYmY3YjQ1. Acesso em: 05/06/2015.
Recebido em: 19/02/2015

Aceito para publicação em: 12/09/2015

Conflito de interesses: nenhum

Fonte de financiamento:

Endereço para correspondência:

Alberto Azoubel Antunes

antunesuro@uol.com.br 